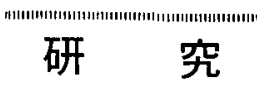

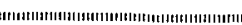

\title{
ケロシンベース磁性流体の磁性，粘性におよぼす温度の影響*
}

\author{
下飯坂 㵎 三**, 中塚 勝 ${ }^{* * *}$ \\ 吉 田洋 一***,山 内 隆 夫****
}

\begin{abstract}
Junzo Shimoiizaka, Katsuto Nakatsuka, Yoichi Yoshida and Takao Yamauchi : Effects of Temperature on the Magnetic Properties and Viscosity of Kerosene Base Magnetic Fluid.

Magnetite powders were prepared by coprecipitation method, and followed by coating of monomolecular oleate ion. The kerosene base magnetic fluids were obtained by dispersing the powders in kerosene. In this paper, the effects of temperature on the chemical stability of surface-coated magnetite, the magnetic properties of magnetic fluid and its viscosity were examined.

The results obtained are as follows: (1) The surface-coated magnetite is oxidized to $a$-hematite in the air at about $200^{\circ} \mathrm{C}$ because of combustion of oleate. (2) The change in the magnetization of magnetic fluid with temperature corresponds to that of magnetite powders. This means that the surface-coated magnetite is fairly stable in kerosene against the change in temperature. (3) Considering that the surface-coated magnetite contains a slight amount of non-magnetic part, the magnetization curve can be explained by Langevin's theory. (4) The magnetic fluids, whose magnetite fractions are less than $0.65 \mathrm{~g} / \mathrm{ml}$, show Newtonian flow. For the dependence of temperature on the viscosity of those fluids, Andrade's equation is applicable to the region of $20^{\circ} \mathrm{C}-80^{\circ} \mathrm{C}$.
\end{abstract}

(Received September 2, 1976)

I 緒 言

ケロシンなどの無極性溶媒をべースとした磁性流体, 拉よび水をべースとした磁性流体の製造方法や $2 ， 3 の$ 性質については既に報告した1,2)。また，エステルをべ 一スとした磁性流体の作成も可能である3)。最近では， てのような磁性流体の笖用に対する検討がなされつつあ り，その報告あ少なくない，例えば，磁性流体を用いた 非磁性物質の比重選別, 軸シール, 油水分離, 表示装置, 検知装置，ダンパー，エネルギー変換など多岐にわたる 応用の途が提案されている4 7)。乙の場合, 磁性流体の 耐熱性, 粘性, 磁気特性あるいは分散安定性などは常に 考虑されるべき特性である.

水ベース磁性流体についてはその安定性に対する温度, pH の影暨について既化報告しているので8)，ここでは， 無極性溶媒をべースとした磁性流体として分散質がマグ ネタイトのケロシンベース磁性流体を取り上げ，表面処 理マグネタイトの被酸化性, 磁性流体の磁気特性拈よび 粘性について檢討した.

\section{II 磁性流体の作成}

ケロシンベース磁性流体の作成法についての詳細は既
報1のごとくであるが，その概要は次の通りである。ま ず，硫酸第一鉄上硫酸第二鉄の等モル混合液に 6 規定の 水酸化ナトリウム溶液を pH 11.0 になるまで加え，乙 れを熟成してマグネタイトコロイドを得た．との賏濁液 にオレイン酸ナトリウムを添加し， $80^{\circ} \mathrm{C} \sim 90^{\circ} \mathrm{C}$ 亿加温 しながら㩭拌する．次にてれを口過脱水後，大気中にて 乾燥し所定量のケロシン中に投入し，ホモジナイザーで 十分覞拌してケロシンベース磁性流体在得た。乾燥粉末 の一部は熱分析用の試料とした。

なお，実験方法については結果の項でそのつど述べる とととする。

\section{III＼cjkstart実験結果および考察}

III-1 表面処理マグネタイトの加熱による酸化 磁性流体の諸特性におよぼす温度の影響についての検 討に先立ち，ととではまず，オレイン酸を吸着させたマ グネタイトの加熱による相変化を調べた．Fig. 1 は種々 のオレイン酸ナトリウム添加量により吸着処理せしめた

* 昭和 50 年 5 月本協会春季大会飞て一部発表, 昭和 51 年 9 月 2 日受理

** 東北大学工学部資源工学科 $\overline{7} 980$ 仙台市荒巻字青葉

*** 東北金属工業(株) T982仙台市郡山6丁目 7 の 1

*****タホー工業(株)中央研究所 7252 藤沢市桐原町 9 


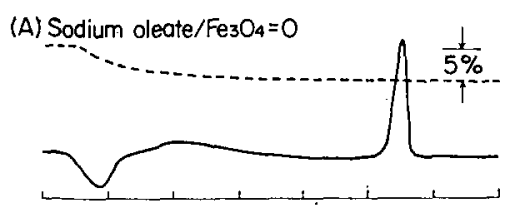

(B) Sodium oleate/ $/ \mathrm{Fe}_{3} \mathrm{O}_{4}=0.15$

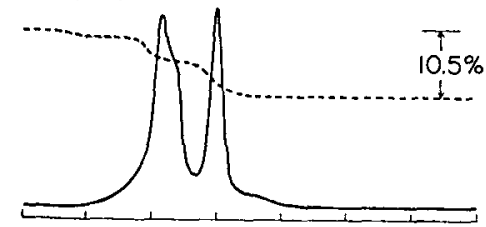

(C) Sodium oleate $/ \mathrm{Fe}_{3} \mathrm{O}_{4}=0.30$

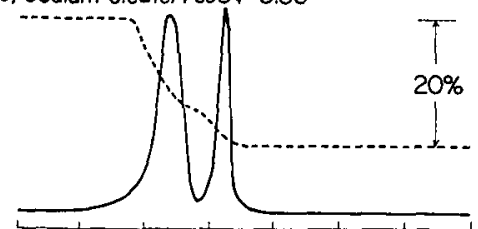

(D) Sodium oleate $/ \mathrm{Ni}-\mathrm{Zn}$ ferrite $=0.30$

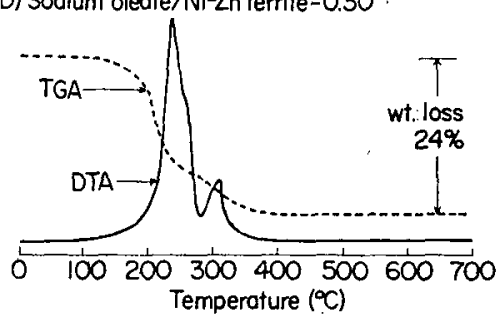

Fig. 1. TGA-DTA curves for surface-coated powders.

マグネタイト粉末を，大気中 $70^{\circ} \mathrm{C} ， 12$ 時間乾燥したむ のについて熱分析を行なった結果である.測定は大気中， 昇温速度 $10^{\circ} \mathrm{C} / \mathrm{min}$ で行なった.（A）は未妈理のマグネ タイト粉末の場合であり示萀熱分析 (DTA) では, $200^{\circ} \mathrm{C}$ 付近にわずかな発熱ピーク，550 $\mathrm{C}$ 付近に強い発熱ピー クが認められる，篗者らが以前検討した結果に上れば， $200^{\circ} \mathrm{C}$ 付近の発熱ピークは酸化によりマグネタイトから $\gamma-\mathrm{Fe}_{2} \mathrm{O}_{3}$ へと変化し, $550^{\circ} \mathrm{C}$ 付近でのを机は， $\gamma-\mathrm{Fe}_{2} \mathrm{O}_{3}$ 加ら $a-\mathrm{Fe}_{2} \mathrm{O}_{3}$ 八亡相軽移するためにあらわれると推察 した9. 一方, TGA では脱水による減量を示しながら， 全体として $5 \%$ 程度の重量減少が認められる. (B), (C)にはオレイン酸で吸着処理したマグネタイト粉末に ついての結果を示す. 最む安定な分散を示すオレイン酸 ナトリウム添加量は $30 \mathrm{~g} / 100 \mathrm{~g} \mathrm{Fe}_{3} \mathrm{O}_{4}$ であり，（C)の 粉末はこの条件で得られたあので（B）は表面処理不足 の粉末である.（B），(C)ともに DTA では $230^{\circ} \mathrm{C}$ 拉 よび $320^{\circ} \mathrm{C}$ 付近に 2 本の発熱ビークがあらわれるが, 末炑理マグネタイト（A)で認められた $550^{\circ} \mathrm{C}$ 付近の発 熱ピークは消失している．これらの試料では吸着曆の変 化の他にマグネタイト自体の相変化が伴い，オレイン酸 の吸着処理による影響のみを明膫に把提しかねるため， (D)には，加熱して屯安定にスピネル相を保持し得る湿
式 $\mathrm{Ni}-\mathrm{Zn}$ フェライト ${ }^{10)}$ を同様に表面姏理した粉末につ いての結果を示した. $230^{\circ} \mathrm{C}$ およ゙ $320^{\circ} \mathrm{C}$ 付近の発熱 ピークは，やはり上述のマグネタイトの場合と同様であ り，乙の 2 本の発熱ピークが酸化や相変化を伴うマグネ タイトのみに認められる特有の現象ではないことを示し ている.

一方，表面姏理された粉末 $(\mathrm{B} \sim \mathrm{D})$ での TGA では， DTA における2本の発熱ピークを示す温度付近で急激 な重量减少が起こっており，その結果，困に示したよう に階段状の曲線となるままた，全体の重量減少は，例 えば(B)，(C)k示されるようにオレイン酸ナトリウム 添加最が増すにつれて增加するとと加ら，TGA の変化 は，主として加光た界面活性剂の变化によるものと思わ れる.このような TGA とDTA との効応性およびTGA とオレイン酸量との相関性加ら， $230^{\circ} \mathrm{C}, 320^{\circ} \mathrm{C}$ 付近の 発熱ピークはオレイン酸が燃焼するために生じたものと 考えられる*.

次に，裴面好理したマグネタイト粉末を大気中で種々 の温度で加熱好理し，得られた粉末についてX線回折を 行ないその結果 Fig. 2 に示した，加熱の㫒温速度は 示差熱分析と同棁 $10^{\circ} \mathrm{C} / \mathrm{min}$ とし，昇温後すみやかに室 温にまで冷却した．丧面処理のみの共沈体ではスピネル 相を示し， $150^{\circ} \mathrm{C}$ に加熱しても罢相はあらわれない。

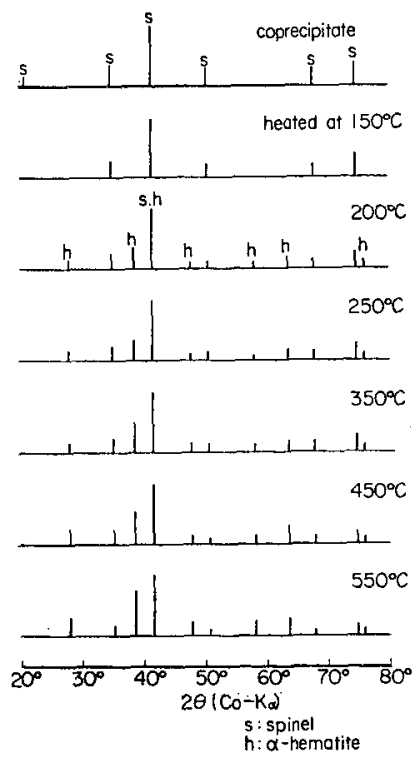

Fig. 2. Changes in X-ray diffraction patterns of surface-coated magnetite with heating.

*オレイン酸被㠅のマグネタイト大氮中で加熱すると， $200^{\circ} \mathrm{C}$ 付近から異暒をとすない白煙を生ずることから，この 温度付近で然焼すると考元られる。な知オレイン酸のみの熱 分析では DTA の変化は顕著ではないが， $200^{\circ} \mathrm{C}$ から著し い重量減少が認められる。 
$200^{\circ} \mathrm{C}$ 加熱試料ではスピネル相の他に $a-\mathrm{Fe}_{2} \mathrm{O}_{3}$ 相があら われるが，ここでのスピネル相にはマグネタイトと $\gamma$ $\mathrm{Fe}_{2} \mathrm{O}_{3}$ 亡が考えられる. $\alpha-\mathrm{Fe}_{2} \mathrm{O}_{3}$ の回折線は，加熱温度 の上昇とともにその强度を増しているととから，スピネ ル相に対する $a-\mathrm{Fe}_{2} \mathrm{O}_{3}$ 析出毁の割合が次第に増加して いることがわかる. Fig. 2 で示された結果は，曻温速度

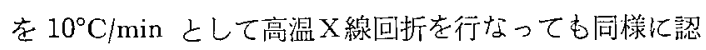
められる. とのように表目処理をしたマグネタイトでは $200^{\circ} \mathrm{C}$ 以上の加熱により $a-\mathrm{Fe}_{2} \mathrm{O}_{3}$ を析出することから， 示差熱分析ではオレイン酸を吸着した粒子に垫められる 2 本の発熱ピークに，上記の $\alpha-\mathrm{Fe}_{2} \mathrm{O}_{3}$ 析出による発熱ピ 一クが重曽したよ考えられる。

以上より，オレイン酸により表面処理されたマグネタ イトは，未好理のマグネタイトに比して，大気中の加熱 では加えた界面活性昘の然㜔により酸化および相变化が 促進されるものと思执れる. この結果怙，ケロシンベー ス磁性流体の㵶造工程上，表面好理マグネタイトの乾燥， 保存等に関連して特に重要である.

III -2 磁化の湍度依存性

磁性流体の示す磁化活その中に含まれるマグネタイト 粒子によるものでする加ら，磁化の温度依存性は，通常 の強磁性体に認められると同様の傾问を示すと考えられ る. Fig. 3 にはケロシンベース磁性流体の温度一磁化曲 線を示した，测定は，溶媒の蒸発を避けるため試料を石 英力プセル中に封入し， $320^{\circ} \mathrm{C}$ まで加熱した. 図に示さ れるように磁性流体の温度一磁化曲線はマグネタイト粒 子のそれ之ほぼ一致し，磁性粒子の磁気的性質估磁性流 体中に扣いても変化しないととがわかる. 前項で述べた ように浪面処理したマグネタイト粒子は酸化されやすく， 磁化を減少させる原因となるが上の結果はこれと異なり， ケロシン中では酸化に対して極めて安定であると考えら れる.

Fig. 4 には，ケロシンベース磁性流体（マグネタイト 濃度 $\theta=0.487 \mathrm{~g} / \mathrm{ml}(に つ い て の ~ \sigma-H / T$ 明線 $(\sigma:$ 磁性流 体の磁化， $H$ : 磁場， $T$ : 絶刘温度)を示した。 $77^{\circ} \mathrm{K}$ お よび $293^{\circ} \mathrm{K}$ いずれの場合す一つの曲線上に示され，朋 いたマグネタイト粒子は超常磁性であるととがわかる*. このような超常磁性を示す粒子の集団が，粒子一粒子間 の相互作用を無視できる程度に十分分散していれば，を の $\sigma \cdot \mathrm{H} / \mathrm{T}$ 曲線は Langevin の常磁性理論により解釈さ れると考えられる，いま，磁性流体の磁化 $\sigma$ が，磁性流 体中のマグネタイト濃度により一義的に決定されるとす ると，。は次式のごとくに示される.

$$
\frac{\sigma}{\sigma_{s}}=\operatorname{coth} \frac{M_{s} m H}{k T}-\frac{k T}{M_{s} m H}
$$

\footnotetext{
*本法により生成せしめたマグネタイト粒子が超常磁性を示す ことについては，メスバウア效果の測定から屯確かめられて (いる"
}

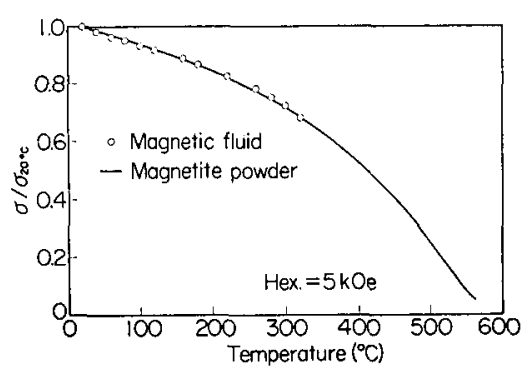

Fig. 3. Magnetization as a function of temperature.

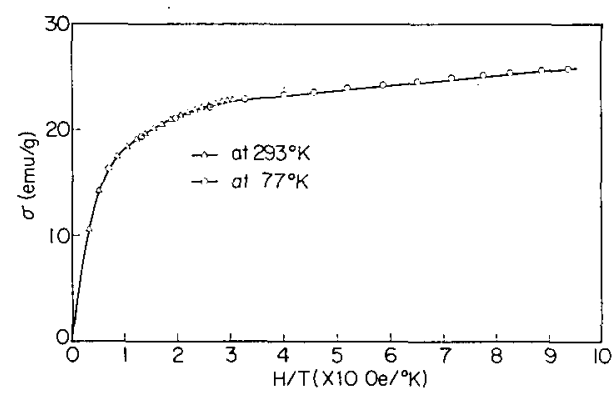

Fig. 4. Magnetization curve of magnetic niuid as a function of $\mathrm{H} / \mathrm{T}$.

但し， $\sigma_{s} M_{s}$ は磁性流体およびマグネタイトの飽和磁化, $m$ はマグネタイト粒子 1 個の重さ， $k$ はボルッマン定数 である，一方， $\sigma_{s}$ と $M_{s}$ との間には次式の関係が成立 するい.

$$
\sigma_{s}=\frac{M_{s}}{\rho} \cdot \frac{\rho-\rho_{L}}{\rho_{C}-\rho_{L}} \cdot \rho_{C}
$$

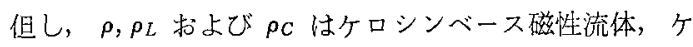
ロシンおよびマグネタイトの密度を示す。原柱磁性流体 の磁化曲線より図式的に求め*，乙れと(2)式より $M_{s}=$ $62 \mathrm{emu} / \mathrm{g}$ を得た. 乙の值を用いて(1)式とのあてはめを 行なえば $m$ が求まり，その結果，粒径は $67 \AA$ と見積 あられる. 以上の数值により $\sigma / \sigma_{s}$ と $M_{s} m H / k T$ とのプ ロットを行ないFig. 5 を得た。図ではLangevin 関数と 実測值との極めてよい一致が羿められ，上の見皘屯りが ほぼ要当であるてとを示している。

一方，純粋なマグネタイトの飽和磁化は $90 \mathrm{emu} / \mathrm{g}$ 亡 考えられているから，てれに此して，上で求めたマグネ タイトの飽和磁化 $62 \mathrm{emu} / \mathrm{g}$ は約30960磁化隇少となる. この原因がマグネタイト夜面の变質による非磁性化のた めと考えると，粒径 $67 \AA$ の微粒子の約 $30 \% 6$ の体皘分だ 啡磁性化したことに相当する。表面上り均一な厚さ $(d)$ で非磁性層が生成したとすれば， $d=4 \AA$ 亡求まる．乙の ような問題について，Kaiser らは，表面処理に用いたオ レイン酸の官能基 $(-\mathrm{COOH})$ が鉄酸化物と反応し，磁

* $\sigma-1 / \mathrm{H}$ 曲線を作成し， $1 / \mathrm{H} \rightarrow 0$ K外捕したときの $\sigma$ を $\sigma_{s}$ と した. 


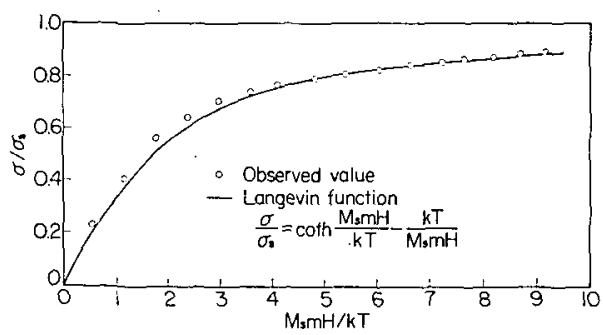

Fig. 5. Superposition of observed magnetization on Langevin function.

性を示さないオレイン酸鉄が生成するととを述へており， 天然マグネタイトの粉碎座物に対して非磁性層の厚さを $a=8.3 \AA$ と古れば，その磁性が合理的化説明されると している11). $d=8.3 \AA$ は本実験で推察された値に比して 大きいが，Kaiser らは磁性流体を得るのに天然のマグ ネタイトを長時間粉砕していることから，このととが、 グネタイト表面の非磁性化を促進させたと委考えられる。 筆者らの表面炠理法で作成した水ベース磁性流体に対し

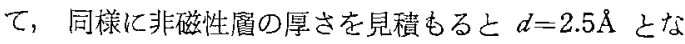
り，磁化減少の原因がオレイン酸鉄の生成のみによる之 は若え難い。

本実験では，水ベース磁性流体よりもケロシンベース 磁性流体の方が磁化の減少が大きく，後者磁性流体作成 には表面処理したマグネタイトの乾燥を伴う点で前者と 異なり，磁化減少の佰因は，用いた界面活性剂よマグネ タイトとの化学的反応の他に, 前項で述べたどとくの酸 化現象屯関与しているものと推察される.

\section{III -3 粘度の温度依存性}

常温におけるケロシンベース磁性流体の流動パターン と濃度との関係は，流動曲線の解析より磁性流体中のマ グネタイト䠞度 $\theta=0.65 \mathrm{~g} / \mathrm{ml}$ を境として，これより低濃 度側ではニュートン流動，离濃度側では擬塑性流動を示 すことがわかった，界面活性剤の吸着畨を考虑して実效 の体皘分率 $\varphi$ を想定すると， $\theta=0.65 \mathrm{~g} / \mathrm{ml}$ は $\varphi=0.60$ に相当する*．また，てのような $\varphi$ を用いてケロシンベ

*界面活性剂の吸着層の厚さをるとすると, $\varphi$ は次式で示され る.

$$
\varphi=\varepsilon\left(1+\frac{\delta}{r}\right)^{3}, \quad \begin{aligned}
& \varepsilon: \text { マグネタイトの体積分率 } \\
& r: \text { マグネタイトの半徍 }
\end{aligned}
$$

一般反懸濁液の此粘度 $\eta_{s p}$ は

$$
\eta_{\mathrm{sp}}=k_{1} \varphi+k_{2} \varphi^{2}+k_{3} \varphi^{3}+\ldots,
$$$$
k_{1}, k_{2}, k_{3} \text { : 定数(但し } k_{1}=2.5 \text { ) }
$$

と示されるから濃度が無限小の極限考考えると

$$
\lim _{\varepsilon \rightarrow 0}\left(\eta_{\mathrm{sp}} / \varepsilon\right)=k_{1}\left(1+\frac{\hat{\delta}}{r}\right)^{3}
$$

以上の手法をケロシンベース磁性流体火適用し

$$
k_{1}\left(1+\frac{\delta}{r}\right)^{3}=11.0, \quad \therefore \varphi=4.4 \varepsilon
$$

の関保を得た。

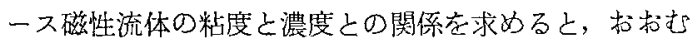
极次の Vand の式12) で示される.

$$
\ln \eta_{\mathrm{r}}=\frac{2.5 \varphi+2.70 \varphi^{2}+\ldots}{1-0.609 \varphi}
$$

但し，ここで $\eta_{\mathrm{r}}$ は相対粘度である。

Fig. 6 はニュートン流動を示す濃度の異なるいくつか のケロシンベース磁性流体について，粘度りを $1 / T(T:$ 絶対温度) に刘してプロットしたあのである. 測定温度 は $20^{\circ} \mathrm{C}, 40^{\circ} \mathrm{C}, 60^{\circ} \mathrm{C}$ 就よ゙ $80^{\circ} \mathrm{C}$ とした、いずれの試料 に㧤いて李 $\log \eta-1 / T$ 良い直線性を示し，測定温度 筑䀦内で Andrade の式 ${ }^{13}$

$$
\eta=A \exp \left(E_{\eta} / R T\right)
$$

が成立している. ここで $A$ は定数， $R$ は気体定数, $E_{\eta}$ は流動に関す百見加けの活性化エネルギーである。 Fig. 7 には Fig. 6 の直線勾配より求めた $E_{\eta}$ を示した

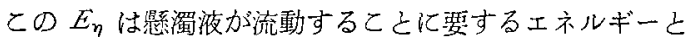
洘えられ，流動しやすさを増すた奴は $E_{\eta}$ が小さいこ と，すな⿰ち，粒子が他の位置に移り得るに十分な自由

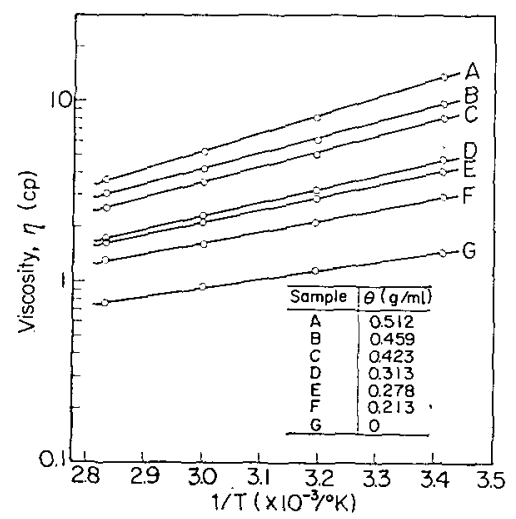

Fig. 6. Fluid viscosity as a function of reciprocal temperature.

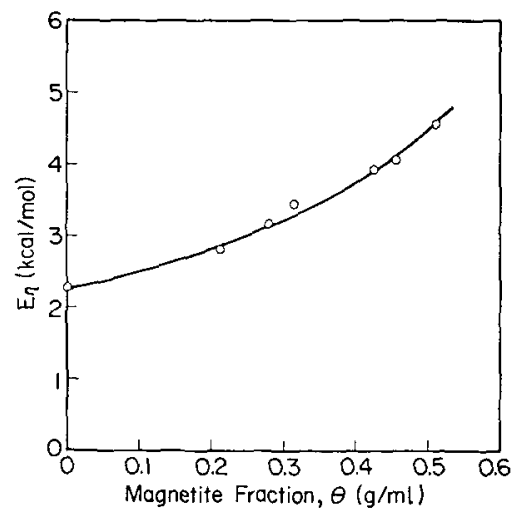

Fig. 7. Activation energy of flow as a function of magnetite fraction. 


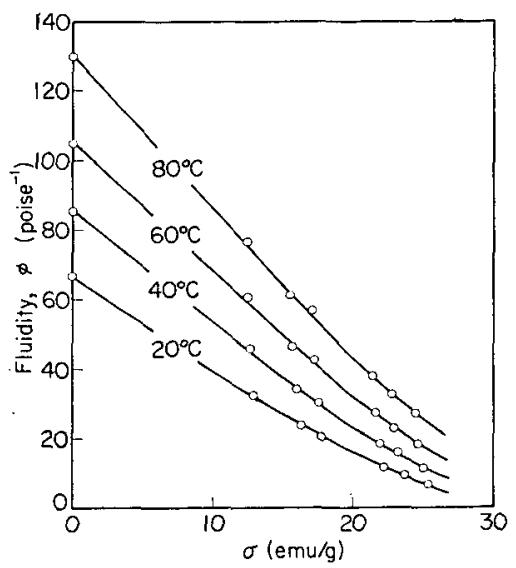

Fig. 8. Relation between fludity and magnetization of magnetic fluid.

容積をむつととが必要である. 従って各粒子が相互に接 触しはじめる濃度で粘度の計算値は極端に大きくなり， $E_{\eta}$ むまた大きくなると考えられる。このような莀度は 例えば最密充填配列ならば74\%である．塞効の体積分率 を考慮して $\varphi=0.74$ 亿相当するマグネタイト濃度を求め ると, $\theta=0.80 \mathrm{~g} / \mathrm{ml}$ となる. Fig. 7 の結果では, マグネ タイト濃度の增加ととあに $E_{\eta}$ 屯增加しており， $E_{\eta}$ は $\theta=0.60 \mathrm{~g} / \mathrm{ml}$ 洷るまで更に增加するように考えられる が，実際には $\theta=0.60 \mathrm{~g} / \mathrm{ml}$ より高濃度側では、ニュート ン流体としての性質は保持し得ない。

以上，磁化书よび粘度の温度依存性について述べたが， このように磁性流体にあっては，その主要な特性である 磁化，粘度がともに温度の影響を強く受けることが特徴 的である.Fig. 8 には，乙枕での結果をまとめて，ケ ロシンベース磁性流体の流動度 $\phi(\phi=1 / \eta)$ と磁化 $\sigma$ と の関係を温度をパラメーターとして示した。一般には磁 性流体の流動度，磁化と屯にできるだけ大きいてとが望 ましいが，Fig. 8 に示されるように，磁化の大きいもの は流動度は小さいしかし一定のマグネタイト濃度に対 しては，例えば $100^{\circ} \mathrm{C}$ 以下であるならば，粘度の温度依 存性の方方磁化のそれより无大さい，磁性流体の使用に 際しては，その使用条件とFig. 8 亿示される関係とを勘 案して, 適当な湏度のあのを選択するてとが重要である.

\section{N 結 論}

ケロシンベース磁性流体の諸性質を検討するために，
浸面処理したマグネタイト粒子の被酸化性, 磁性流体の 磁気特性拉よび粘性などにおよぼす温度の影響について 榆討し次の結諭を得た.

（1）オレイン酸によって表面处理されたマグネタイトを 大気中で加熱すると，吸着しているオレイン酸の燃燒に 上り酸化が促進さ机， $200^{\circ} \mathrm{C}$ で $\mathrm{a}-\mathrm{Fe}_{2} \mathrm{O}_{3}$ 相を析出しは じぬる.

（2）磁性流体の温度一磁化曲線はマグネタイト粒子のそ れとほぼ一致し，表面処理されたマグネタイト粒子はケ ロシン中では酸化に対して安定である。

（3）マグネタイト粒子の体積の約 $30 \%$ が非磁性化してい るとすれば，磁性流体の磁化曲線は Langevin の常磁性 理諭により合理的に説明される.

（4）磁性流体の粘度の温度依存性は，二ュートン流動を 示寸試料（マグネタイト瀇度 $\theta=0.65 \mathrm{~g} / \mathrm{ml}$ 以下）に対し て，いわ奶る Andrade の式が成立する。

本研究の費用の一部は昭和 50 年度文部省科学研究費補 助金(043004)によったことを記し，謝意を表する次第で ある。また, 東北金属工業(株)ならびにタイホ一工業(株) 䦎係各位には犁々の御支挼老頂いたこと，東北大学大学 院生中鉢良治君には実験の協力を得たてとを記し樑謝す る.

\section{文献}

1）下飯坂，中塚，中錸，佐藤：粉体招上び粉末治金，22 (1975), 22.

2）下飯坂, 中塚，中鉢，佐藤：日本化学会誌，1 (1976), 6.

3）下飯坂, 中銖, 中塚, 吉田：日本化学会第 34 春季年会講 演予稿集 I，(1976)，231。

4) R. E. Rosensweig, J. W. Nestor and R. M. Timmins: A. I. Ch. E. Symposium Series, No. 5104, (1965).

5) Nicholas R. Iammartino: Chemical Engineering, Jan. $21,(1974) 74$.

6) 可知佑次：固体物理, 8(1973), 449.

7）下飯坂：日本金属学会報, 15, [2] (1976), 77.

8）中錰，中域，下飯坂：粉体括よび粉末治金，23(1976), 211.

9) 佐藤, 中塚, 戸板, 下飯坂: 粉体招上び粉末治金, 14 (1967), 71.

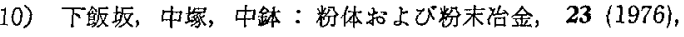
85.

11) R. Kaiser and G. Miskolczy: Journal of Applied Physics, 41 (1970), 1964.

12) V. Vand: Journal of Physical Chemistry, 52 (1948), 277.

13）後藤，平井，花井共著：しオロジーとその忘用，共立出 版(株)，(1962)，49. 